\title{
PKM: Pelatihan Relaksasi Nafas Ballon Blowing Untuk Meningkatkan Saturasi Oksigen Pada Warga Desa Bungkulan Singaraja
}

\author{
Ni Made Dwi Yunica Astriani ${ }^{* 1}$, Putu Agus Ariana ${ }^{2}$, Putu Indah Sintya Dewi ${ }^{3}$, Mochamad Heri ${ }^{4}$, \\ Errick Endra Cita ${ }^{5}$ \\ 1,4,5 Prodi Profesi Ners STIKes Buleleng Bali Indonesia \\ 2,3Prodi S-1 Keperawatan STIKes Buleleng Bali Indonesia \\ *Penulis Korespondensi, Ni Made Dwi Yunica Astriani, Prodi Profesi Ners STIKes Buleleng \\ Email : astrianiyunica1@gmail.com
}

\begin{abstract}
ABSTRAK
PPOK merupakan penyakit kronis saluran nafas yang ditandai dengan adanya hambatan aliran udara yang bersifat progresif lambat, yang disebabkan oleh pajanan faktor risiko seperti merokok, polusi udara, penyakit PPOK biasanya terjadi pada usia pertengahan dan tidak biasa hilang dengan pengobatan. Seseorang dikatakan PPOK apabila pernah mengalami sesak napas bertambah jika beraktifitas atau bertambah dengan meningkatnya usia disertai batuk berdahak, atau pernah mengalami sesak napas disertai batuk berdahak. Saturasi oksigen ada pasien PPOK dapat mengalami penurunan sampai $85 \%$ yang dapat mengakibatkan hipoksemia, sianosis. Relaksasi pernapasan mempunyai banyak teknik salah satunya adalah dengan menggunakan balon (ballon blowing) teknik relaksasi dengan meniup balon dapat membantu otot intracosta mengelevasikan otot diafragma dan kosta. Sehingga memungkinkan untuk menyerap oksigen, mengubah bahan yang masih ada dalam paru dan mengeluarkan karbondioksida dalam paru. Permasalahan warga Desa Bungkulan belum pernah diadakan pemberian edukasi tentang relaksasi nafas dengan tehnik ballon blowing. Selain itu, kurangnya pengetahuan tentang relaksasi nafas dengan tehnik ballon blowing pada pasien PPOK. Tujuan kegiatan PKM ini adalah meningkatkan pengetahuan dan keterampilan mitra dalam tehnik latihan nafas ballon blowing. Metode yang digunakan adalah ceramah/penyuluhan, tutorial dan demonstrasi latihan nafas ballon blowing. Hasil kegiatan ini meningkatkan pemahaman dan pengetahuan warga desa Bungkulan tentang konsep penyakit PPOK dan latihan nafas ballon blowing. Pengingkatan Keterampilan sebesar $80 \%$ dalam Latihan nafas Ballon Blowing.
\end{abstract}

Kata kunci : Ballon Blowing, Pelatihan, Saturasi Oksigen

\section{ABSTRACT}

COPD is a chronic airway disease characterized by slow progressive airflow obstruction, which is caused by exposure to risk factors such as smoking, air pollution, COPD disease usually occurs in middle age and does not usually disappear with treatment. A person is said to have COPD if they have experienced shortness of breath with increased activity or increase with age accompanied by a cough with phlegm, or have experienced shortness of breath accompanied by a cough with phlegm. Oxygen saturation in COPD patients can be decreased by up to $85 \%$ which can lead to hypoxemia, cyanosis. Breathing relaxation has many techniques, one of which is by using a balloon (balloon blowing). The relaxation technique by blowing $a$ balloon can help the intracostal muscles to elevate the diaphragm and costal muscles. So that it 
is possible to absorb oxygen, change the material that is still in the lungs, and remove carbon dioxide in the lungs. The problem of the residents of Bungkulan Village has never been to provide education about relaxation of breath with the ballon blowing technique. Also, there is a lack of knowledge about breath relaxation with ballon blowing techniques in COPD patients. The purpose of this PKM activity is to improve partners' knowledge and skills in balloon blowing breath training techniques. The method used is lectures/counseling, tutorials, and demonstrations of ballon blowing breath exercises. The results of this activity increase the understanding and knowledge of Bungkulan villagers about the concept of COPD and ballon blowing breathing exercises. 80\% Skill Increase in Ballon Blowing Breath Training.

Keywords: Balloon Blowing, Training, Oxygen Saturation

\section{PENDAHULUAN}

\section{ANALISIS SITUASI}

\section{A. Kondisi Mitra}

PPOK merupakan sebagai suatu penyakit yang ditandai dengan adanya obstruksi saluran pernafasan yang tidak reversible sepenuhnya. Sumbatan aliran udara ini umumnya bersifat progresif dan berkaitan dengan respon inflamasi abnormal paru-paru terhadap partikel atau gas yang berbahaya. Serangan akut dan komorbiditas berpengaruh terhadap keparahan penyakit secara keseluruhan. Beberapa rumah sakit di Indonesia menggunakan istilah PPOM (Penyakit Paru Obstruksi Menahun) yang merujuk pada penyakit yang sama. (Ikawati, 2011).

Penyebab PPOK yaitu polusi udara merupakan penyebab utama dan tersering, karena setiap hari manusia melakukan aktivitas menghirup dan mengeluarkan udara, semakin kotor udara, semakin banyak pula kotoran yang masuk kedalam saluran pernapasan manusia. Polutan udara ini dapat berupa asap, debu, gas, maupun uap. Semakin sering seseorang terpapar polutan maka semakin mudah dan semakin cepat seseorang mengalami penyakit saluran pernapasan kronik (Ikawati, 2011).

Asap rokok mengakibatkan iritasi pada bronkus dan alveolus sehingga, mengakibatkan makofrag dan neutrofil berinfiltrasi ke epitel dan mengakibatkan kerusakan pada epitel, produksi mukus berlebih menyebabkan terjadinya sumbatan pada bronkus dan alveoli. Dengan adanya mukus yang kental serta menurunnya pembersihan mukosiliar menyebabkan meningkatnya risiko infeksi (Ikawati, 2011). Sekresi mukus yang berlebih, penyempitan lumen, dan terjadi penyempitan saluran pernapasan pada Bronkitis kronis menyebabkan terjadinya perubahan saluran nafas kecil sehingga menyebabkan berkurangnya ventilasi. Sehingga terjadi ketidakseimbangan antara ventilasi dengan perfusi dan hipoksemia. Hipoksemia mengakibatkan suplai oksigen menurun sehingga dapat menyebabkan penurunan saturasi oksigen.

Saturasi oksigen merupakan rasio antara jumlah oksigen aktual yang diangkut oleh hemoglobin terhadap kemampuan total hemoglobin darah mengikat oksigen. Saturasi oksigen ada pasien PPOK dapat mengalami penurunan sampai $85 \%$ yang dapat mengakibatkan hipoksemia, sianosis. Nilai normal saturasi oksigen yang diukur dengan menggunakan oksimetri nadi yaitu 95-100\%. Saturasi oksigen digunakan untuk mengukur persentase oksigen yang diikat oleh hemoglobin didalam aliran darah (Djojodibroto, 2014).

Saturasi oksigen pasien PPOK dapat ditingkatkan dengan terapi nonfarmakologi yaitu relaksasi pernafasan yaitu nafas dalam 
diindikasikan pada pasien PPOK dan dispnea.

Relaksasi pernapasan mempunyai banyak teknik salah satunya adalah dengan menggunakan balon (ballon blowing) teknik relaksasi dengan meniup balon dapat membantu otot intracosta mengelevasikan otot diafragma dan kosta. Sehingga memungkinkan untuk menyerap oksigen, mengubah bahan yang masih ada dalam paru dan mengeluarkan karbondioksida dalam paru. Meniup balon sangat efektif untuk membantu ekspansi paru sehingga mampu mensuplai oksigen dan mengeluarkan karbondioksida yang terjebak dalam paru pada pasien dengan gangguan fungsi pernapasan. Peningkatan ventilasi alveoli dapat meningkatkan suplai oksigen, sehingga dapat dijadikan sebagai terapi dalam peningkatan saturasi oksigen. Dalam hal ini perawat menganjurkan kepada klien relaksasi pernafasan yaitu nafas dalam dengan teknik meniup balon. Anjurkan klien bagaimana cara menghirup udara melalui hidung dengan lambat menahan inspirasi dan mengeluarkan melalui mulut kedalam balon secara maksimal. (Tunik et al., 2017)

\section{Permasalahan Mitra}

Berdasarkan hasil survey yang telah dilakukan maka permasalahan mitra adalah : warga Desa Bungkulan belum pernah diadakan pemberian edukasi tentang relaksasi nafas dengan tehnik ballon blowing. Selain itu, kurangnya pengetahuan tentang relaksasi nafas dengan tehnik ballon blowing pada pasien PPOK. Dari hasil wawancara dengan beberapa warga desa didapatkan bahwa jika mereka sakit langsung berobat ke puskesmas dan hanya diberikan obat oleh petugas kesehatan. berdasarkan hasil observasi dengan 2 orang pasien PPOK di dapatkan rata-rata hasil frekuensi pernafasan yaitu $\pm 25 /$ menit. Dari hasil pemeriksaan saturasi oksigen didapatkan 3 orang pasien dengan saturasi oksigen dibawah normal dan, 1 orang pasien memiliki saturasi oksigen dengan rata-rata normal.

\section{Tujuan dan Manfaat Kegiatan}

Berdasarkan hasil analisis situasi dan permasalahan yang berhasil diidentifikasi, maka tujuan kegiatan PKM ini adalah meningkatkan pengetahuan dan keterampilan mitra dalam tehnik latihan nafas ballon blowing.

\section{METODE PELAKSANAAN \\ Lokasi Kegiatan}

rumah $\begin{gathered}\text { Kegiatan PKM ini dilaksanakan di } \\ \text { masing-masing warga desa }\end{gathered}$ Bungkulan sebanyak 15 orang.

\section{Metode yang digunakan}

Kegiatan PKM ini dilaksanakan dengan metode ceramah/penyuluhan, tutorial dan demonstrasi latihan nafas ballon blowing. Kegiatan ceramah/penyuluhan meliputi pengertian PPOK, penyebab PPOK, tanda dan gejala PPOK, latihan nafas ballon blowing. Sedangkan demonstrasinya mempraktekan tehnik latihan nafas ballon blowing.

Penilaian kegiatan dilakukan dalam dua tahap seperti yang disajikan dalam Tabel 1. Penilaian menggunakan skala Likert, rancangan evaluasi disajikan dalam Tabel 2. Selama proses pelatihan dilakukan pengamatan menurut skor $1=$ sangat kurang, $2=$ kurang, $3=$ cukup, $4=$ baik , $5=$ baik sekali. 
Tabel 1. Kegiatan Latihan Nafas Ballon Blowing

\begin{tabular}{|c|c|c|c|c|}
\hline No & Kegiatan & Tujuan & Bentuk kegiatan & Hasil \\
\hline 1 & $\begin{array}{l}\text { Penyuluhan tentang konsep } \\
\text { PPOK dan latihan nafas } \\
\text { ballon blowing }\end{array}$ & $\begin{array}{l}\text { Meningkatkan } \\
\text { pengetahuan } \\
\text { peserta tentang } \\
\text { konsep PPOK dan } \\
\text { latihan nafas ballon } \\
\text { blowing }\end{array}$ & $\begin{array}{l}\text { Ceramah } \\
\text { Diskusi }\end{array}$ & $\begin{array}{l}\text { Materi/bahan } \\
\text { cetak }\end{array}$ \\
\hline 2 & $\begin{array}{l}\text { Demonstrasi latihan nafas } \\
\text { ballon blowing }\end{array}$ & $\begin{array}{l}\text { Meningkatkan } \\
\text { keretampilan } \\
\text { peserta tentang } \\
\text { latihan nafas ballon } \\
\text { blowing }\end{array}$ & Demonstrasi & $\begin{array}{l}\text { Peningkatan } \\
\text { saturasi } \\
\text { oksigen }\end{array}$ \\
\hline
\end{tabular}

Tabel 2. Rancangan Evaluasi Kegiatan

\begin{tabular}{|c|c|c|c|}
\hline No & Kegiatan & Indikator penilaian & Hasil \\
\hline 1 & $\begin{array}{l}\text { Penyuluhan tentang } \\
\text { konsep PPOK dan latihan } \\
\text { nafas ballon blowing }\end{array}$ & $\begin{array}{l}\text { 1. Pengertian PPOK } \\
\text { 2. Penyebab PPOK } \\
\text { 3. Tanda dan Gejala } \\
\text { PPOK } \\
\text { 4. Pengertian Latihan } \\
\text { nafas ballon blowing } \\
\text { 5. Tehnik Latihan nafas } \\
\text { ballon blowing }\end{array}$ & $\begin{array}{l}\text { Menggunakan } \\
\text { dengan } \\
\text { menggunakan skala likert } \\
\text { Skor } 1 \text { = sangat kurang, } \\
\text { Skor } 2 \text { = kurang, } \\
\text { Skor } 3 \text { = cukup, } \\
\text { Skor } 4=\text { baik, } \\
\text { Skor } 5 \text { = baik sekali }\end{array}$ \\
\hline 2 & $\begin{array}{l}\text { Demonstrasi latihan nafas } \\
\text { ballon blowing }\end{array}$ & $\begin{array}{lr}\text { SOP } & \text { Relaksasi } \\
\text { Pernafasan dengan } & \text { Teknik Ballon Blowing : } \\
\text { Tekn } & \text { Tarik nafas } \\
\text { maksimal melalui hidung } \\
(3-4 \text { detik), ditahan } \\
\text { selama 2-3 detik } \\
\text { kemudian } \\
\text { kedalam balon secara } \\
\text { maksimal selama 5-8 } \\
\text { detik sampai balon } \\
\text { mengembang }\end{array}$ & $\begin{array}{l}\text { Menggunakan lembar } \\
\text { observasi dengan } \\
\text { menggunakan skala likert } \\
\text { Skor 1 = sangat kurang, } \\
\text { Skor } 2 \text { = kurang, } \\
\text { Skor } 3 \text { = cukup, } \\
\text { Skor } 4 \text { = baik, } \\
\text { Skor } 5 \text { = baik sekali }\end{array}$ \\
\hline
\end{tabular}

HASIL DAN PEMBAHASAN 
Tabel 3. Usia

\begin{tabular}{llllll}
\hline & N & Mean & Min & Max & Sd \\
\hline Usia & 30 & 61,87 & 45 & 80 & 9.558 \\
\hline
\end{tabular}

Hasil PKM menunjukan bahwa dari 30 warga, mayoritas pasien PPOK berdasarkan usia didapatkan seluruhnya berada pada usia diatas 40 tahun. Hasil penelitian ini sejalan dengan hasil penelitian yang menyatakan bahwa mayoritas pasien PPOK yaitu diatas 40 tahun (Yuningsih \& Islamic, 2017). Semakin bertambahnya usia semakin besar risiko menderita PPOK. PPOK dapat berpengaruh terhadap penurunan fungsi paru dan perubahan fisiologis yang berkaitan dengan penuaan dan mengakibatkan obstruksi jalan napas sehingga mempengaruhi suplay oksigen, elastisitas paru dan gangguan ventilasi paru.

Kegiatan PKM dalam bentuk penyuluhan tentang tentang konsep PPOK dan latihan nafas ballon blowing sebagai upaya peningkatan saturasi oksigen menunjukan adanya peningkatan pengetahuan perseta penyuluhan. Rata-rata pengetahuan peserta sebelum dilakukan penyuluhan adalah sebesar $65 \%$ sedangkan setelah penyuluhan meningkat menjadi $83 \%$ Peningkatan rata-rata nilai tersebut dikarenakan kegiatan penyuluhan yang dilaksanakan sangat disesuaikan dengan kebutuhan peserta penyuluhan. Sejalan dengan PKM yang dilakukan oleh (Ade Irma Nahdliyyah, Nur Achiri M, 2020) tentang Latihan Keseimbangan, Pernafasan Untuk Meningkatkan Aktivitas Fungsional pada Lansia didapatkan hasil peningkatan nilai post test terdiri dari 8 pertanyaan yang berhubungan dengan pengetahuan peserta tentang keseimbangan, latihan pernafasan dan pernah tidaknya melakukan latihanlatihan .

Materi penyuluh dipersiapkan oleh tim PKM menggunakan bahasa yang mudah dipahami oleh peserta sehingga menjadi bahan informasi yang sangat mudah dipahami.hal ini sesuai dengan pengabdian yang dilakukan oleh (Pratiwi et al., 2020) tentang Pemberdayaan Kader Dan Keluarga Dalam Upaya Perbaikan Perubahan Fisik Penderita Tuberculosis Melalui Latihan Pernapasan. Rata-rata pengetahuan meningkat setelah dilakukan penyuluhan yaitu 92,15 .

Kegiatan selanjutnya adalah memberikan domonstrasi latihan nafas ballon blowing. Rata-rata saturasi oksigen tertinggi adalah $99 \%$ Dan terendah adalah 91\% dengan rata-rata saturasi oksigen sebesar 94,53 \%. Hal ini menunjukan bahwa pemberian relaksasi nafas dengan teknik ballon blowing dapat meningkatkan saturasi oksigen pada pasien PPOK. Hasil keterampilan warga tentang latihan nafas ballon blowing meningkat dari $55 \%$ menjadi $80 \%$. Berdasarkan evaluasi kegiatan didapatkan minat warga dalam mengikuti penyuluhan dan pelatihan sebesar $95 \%$.

Pkm ini didukung oleh pkm serupa yang pernah dilakukan (Kartikasari \& Fajriyah, 2019) mengenai Edukasi Latihan Pernapasan Diafragma pada Pasien Asma di Poli Paru Rumah Sakit PKU Muhammadiyah Gamping Yogyakarta dengan 10 pasien asma didapatkan hasil Pada pre-test yang dilakukan pada 10 pasien, didapatkan mean 0,40 dengan standar deviasi 0,16. Pada post-test didapatkan mean 6,0 dengan standar deviasi 0,00. Hasil Paired Sample T-test didapatkan $0,00<0,05$ yang berarti bahwa ada pengaruh edukasi latihan pernapasan diafragma terhadap ketrampilan pasien asma di Poli Paru RS PKU Muhammadiyah Gamping Yogyakarta.

Latihan pernafasan dirancang dan dijalankan untuk mencapai ventilasi. Hal ini dibuktikan dalam pemberian intervensi dengan melatih otot pernafasan serta latihan nafas dalam secara teratur terbukti efektif 


\section{UCAPAN TERIMA KASIH}

meningkatkan ekspansi dada dan paru yang berdampak pada saturasi oksigen pasien.

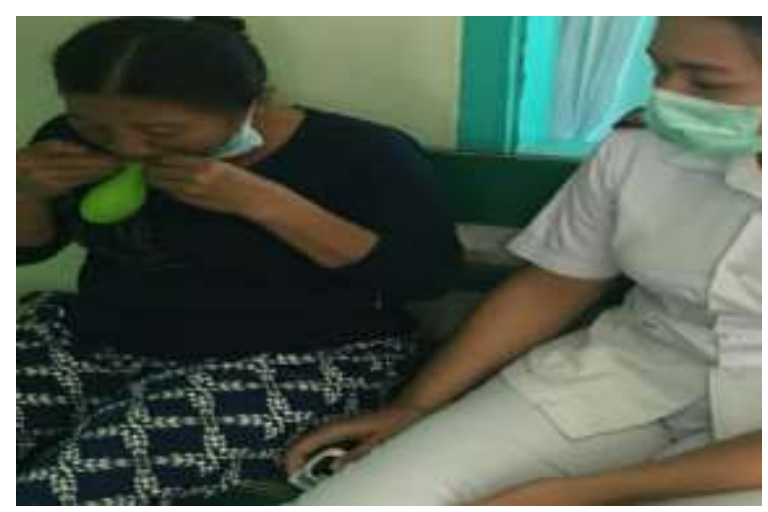

Gambar 1. Latihan Nafas Ballon Blowing

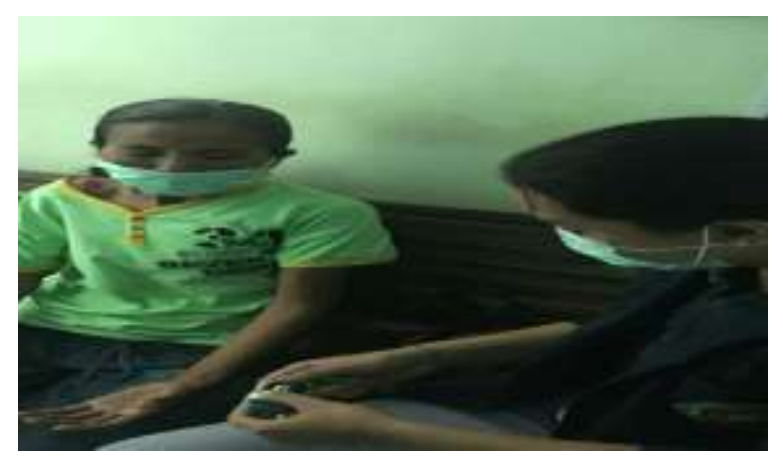

Gambar 2. Pengecekan Saturasi Oksigen

\section{KESIMPULAN DAN SARAN}

Kegiatan PKM ini telah meningkatkan pemahaman dan pengetahuan warga desa Bungkulan tentang konsep penyakit PPOK dan latihan nafas ballon blowing. Pengingkatan Keterampilan dalam Latihan nafas Ballon Blowing dan peningkatan nilai saturasi oksigen.

\section{Saran}

Tetap dilakukanya pendampingan dan monitoring kegiatan secara berkesinambungan kepada warga desa Bungkulan sehingga dapat meminimalkan terjadi nya kekurangan saturasi oksigen dalam tubuh.
1. Ketua STIKES Buleleng, yang telah memberikan motivasi dan dukungan selama kegiatan PKM yang telah dilakukan.

2. LPPM STIKES Buleleng

3. Warga Desa Bungkulan yang sangat kooperatif saat kegiatan berlangsung

4. Mahasiswa yang terlibat dalam Kegiatan PKM ini.

\section{DAFTAR PUSTAKA}

Ade Irma Nahdliyyah, Nur Achiri M, T. A. dkk. (2020). Tema: Latihan Keseimbangan, Pernafasan Untuk Meningkatkan Aktivitas Fungsional pada Lansia. Abdimas, 1(1), 20-29.

Djojodibroto,

D.

Respirologi(Respiratory Medicine) (J. S. Melinda (ed.); 2nd ed.). Penerbit Buku Kedokteran EGC.

Ikawati, Z. (2011). Penyakit Sistem pernafasan dan Tatalaksana terapinya (Anindya (ed.)). Bursa Ilmu.

Kartikasari, D., \& Fajriyah, N. N. (2019). Edukasi Latihan Pernapasan Diafragma pada Pasien Asma di Poli Paru Rumah Sakit PKU Muhammadiyah Gamping Yogyakarta. The 10th University Research Colloqium 2019 Sekolah Tinggi Ilmu Kesehatan Muhammadiyah Gombong, 1050-1053.

Pratiwi, I. N., Pendidikan, P. S., Keperawatan, N. F., Airlangga, U., Mulyorejo, K. C., Pendidikan, P. S., Keperawatan, N. F., Airlangga, U., Mulyorejo, K. C., Dewi, L. C., Pendidikan, P. S., Keperawatan, N. F., Airlangga, U., \& Mulyorejo, K. C. (2020). Pemberdayaan Kader Dan Keluarga Dalam Upaya Perbaikan Perubahan Fisik Penderita Tuberculosis 
VIVABIO

Jurnal Pengabdian Multidisiplin
Melalui Latihan Pernapasan. Journal of Community Engagement, 1(1), 24-31.

Tunik, Rosa, E. M., \& Khoiriyati, A. (2017). pengaruh Breathing Relaxtation dengan Teknik Ballon Blowing Terhadap Saturasi Oksigen dan Perubahan Fisiologs Kecemasan Pasien dengan PPOK.
Yuningsih, \& Islamic. (2017). Pengaruh Latihan Nafas Dalam Terhadap Peningkatan Saturasi Oksigen Pada Klien Terpasang WSD Di RSUD Kabupaten Tangerang. 